\title{
Surface coagulation and microbial respiration in response to local advection and sea state in the North Atlantic
}

\author{
P. E. Kepkay \\ Biological Oceanography Division, Department of Fisheries and Oceans, Bedford Institute of Oceanography, PO Box 1006, \\ Dartmouth, Nova Scotia, Canada B2Y 4A2
}

\begin{abstract}
Microbial respiration in the upper ocean is enhanced by the coagulation of colloidal dissolved organic carbon on bubble surfaces. This large and transient enhancement of respiration by surface coagulation is typical of both coastal and oceanic waters, but is also affected by smaller-scale factors such as sea state and the local advection of water masses. These 2 factors were in evidence during bubbling experiments carried out at 40 and $44^{\circ} \mathrm{N}$ in the western North Atlantic. At the beginning of a time series of experiments, natural bubbling associated with relatively high sea states (2 to $4.5 \mathrm{~m}$ swells under winds of 12 to $22 \mathrm{~m} \mathrm{~s}^{-1}$ ) allowed only a limited potential for the enhancement of respiration by bubbling in a glass column. At lower sea states later in the time series, the advection of water with different biological characteristics produced results that were similar to those from earlier studies in bubbling columns, i.e. the induction of strong and transient peaks of microbial respiration. When rebubbling experiments were carried out after the initial time series, there appeared to be no further enhancement of respiration by bubbling once the initial, transient peak of respiration was generated. Together, the times series and rebubbling experiments suggest that sea state and local advection may be closely linked in their regulation of microbial respiration in the upper ocean.
\end{abstract}

\section{INTRODUCTION}

Given the significance of dissolved organic carbon (DOC) in seawater as a global reservoir of carbon (Hedges 1987, Toggweiler 1988), surface coagulation, or the coagulation of DOC on bubble surfaces to form aggregates, may be an important process in the mediation of carbon flux in the surface ocean. Since the initial work of Sutcliffe et al. (1963), there have been many conflicting reports on the oceanographic and ecological importance of surface coagulation. Johnson et al. (1986) and Kepkay \& Johnson $(1988,1989)$ resolved many of these conflicts by demonstrating that realistic physical constraints should be used in bubbling experiments. They found that filtration of DOC is critical in determining whether aggregates are formed by surface coagulation; bubble size and the distance risen by bubbles in a bubbling column were also important factors. Filtering seawater through filters finer than 2 $\mu \mathrm{m}$ in pore size removes larger colloids in the 0.2 to 2.0 $\mu \mathrm{m}$ size range - the most important source of DOC for coagulation onto bubble surfaces. In addition, when compared to bubbles less than $200 \mu \mathrm{m}$ in diameter, 500 $\mu \mathrm{m}$ bubbles are far more efficient at scavenging DOC as they rise through a column of water.

With proper control of filtration, bubble size and rise distance, bacteria are not required for aggregate formation but, within hours, become an important component of the aggregates generated (Johnson et al. 1986, Kepkay \& Johnson 1988). In ocean environments ranging from coastal waters (Kepkay \& Johnson 1988) to unproductive surface water in the Sargasso Sea (Kepkay \& Johnson 1989, Kepkay et al. 1990a) and productive, particle-rich waters on Georges Bank (Kepkay et al. 1990b), a burst of microbial respiration is induced by surface coagulation and lasts for only 2 to $4 \mathrm{~h}$. This rapid, but transient, microbial response to surface coagulation would not normally be detected in standard, $24 \mathrm{~h}$ dark-bottle incubations (Kepkay et al. 1990a) and is always followed by a short-lived ( 4 to $6 \mathrm{~h}$ ) increase in bacterial number.

While it is now clear that surface coagulation in a bubbling column has a direct and reproducible effect on microbial respiration, additional problems are 
encountered when the microbial consequences of bubbling in natural environments are inferred from experimental results. All the evidence to date has been obtained from seawater sampled during relatively low sea states (with swell heights of $2 \mathrm{~m}$ or less). No attention has been paid to the effects of natural bubbling at higher sea states on the results obtained from bubbling columns. In this paper, I delineate the effects of sea state and surface water advection on the respiratory response to surface coagulation in the North Atlantic.

\section{MATERIALS AND METHODS}

Seawater collection and preparation. In April and May 1989, seawater was collected during CSS 'Baffin' cruise 89-003. This cruise was carried out as part of JGOFS (Joint Global Ocean Flux Study) and its focus on the spring bloom in the North Atlantic. Water was collected from a depth of $10 \mathrm{~m}$ by Niskin bottle cast at a drift station occupied for $6 \mathrm{~d}$ at $40^{\circ} 32^{\prime} \mathrm{N}, 47^{\circ} 10^{\prime} \mathrm{W}$. For $5 \mathrm{~d}$ prior to occupation of the station, the region was subjected to storm conditions, with wind speeds of about $20 \mathrm{~m} \mathrm{~s}^{-1}$ and swell heights of 4 to $5 \mathrm{~m}$ (Fig. 1). By the time the station was occupied, wind speed had decreased to 5 to $10 \mathrm{~m} \mathrm{~s}^{-1}$ and swell heights had decreased to 1 to $2 \mathrm{~m}$.
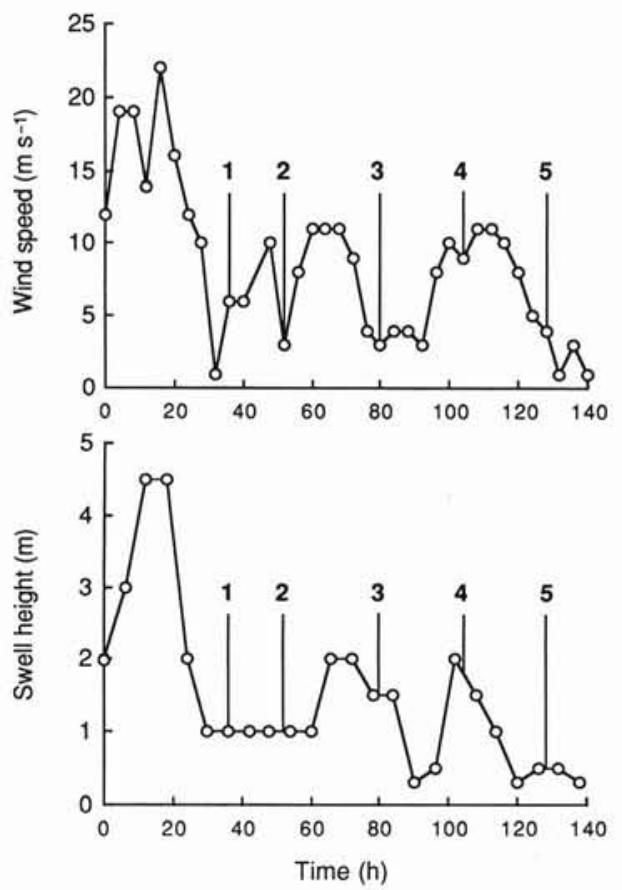

Fig. 1. Wind speeds and swell heights recorded at a drift station occupied for $6 \mathrm{~d}$ at $40^{\circ} 32^{\prime} \mathrm{N}, 47^{\circ} 10^{\prime} \mathrm{W}$ in the N Atlantic during April and May 1989 as part of the JGOFS (1989) study of the spring bloom. The location of a time series of 5 respiration experiments carried out at $24 \mathrm{~h}$ intervals is superimposed on each plot to show the sea states encountered before and during the experiments
Eight liters of the unfiltered seawater were bubbled for 30 min on board ship in an enclosed glass column similar to the one described by Johnson et al. (1986). Compressed air was passed through a 10 to $20 \mu \mathrm{m}$ glass frit at a flow rate of $100 \pm 20 \mathrm{ml} \mathrm{min}^{-1}$ to produce bubbles 340 to $1960 \mu \mathrm{m}$ in diameter (average diameter $487 \mu \mathrm{m}$ ). The air supplied to the frit was prefiltered through activated carbon and a sterile $0.2 \mu \mathrm{m}$ filter cartridge (Gelman) to ensure that contaminants were not introduced on bubble surfaces. After bubbling, duplicate 21 batches of the seawater were gently stirred in the dark at in situ temperature $\left(15.0\right.$ to $\left.16.5^{\circ} \mathrm{C}\right)$. Additional 21 batches of unfiltered seawater were also stirred at in situ temperature as unbubbled controls and, at intervals over times up to and including $30 \mathrm{~h}$, samples were taken from the bubbled and unbubbled seawaters for ship-board measurement of respiration. A rebubbling procedure was also used in an additional time series of bubbling experiments at a station occupied for $5 \mathrm{~d}$ at $44^{\circ} 50^{\prime} \mathrm{N}, 41^{\circ} 23^{\prime} \mathrm{W}$. The same methods were followed as those at $40^{\circ} \mathrm{N}$, but with one important modification. An additional 41 batch of bubbled seawater from the first experiment at this new station was aged at in situ temperature $\left(11.0^{\circ} \mathrm{C}\right)$ before being used the following day in a second bubbling experiment.

Temperature, salinity, chlorophyll and primary production. Water temperature and salinity were profiled using a CTD (Guildline). Water samples taken at the same time by Niskin bottle cast were analyzed using standard techniques to measure bulk chlorophyll $a$ on Whatman GF/F filters (Holm-Hansen et al. 1965). Primary production was determined using the radiotracer ${ }^{14} \mathrm{C}$ method (Steemann Nielsen 1952) and in situ incubations from dawn to dusk (Irwin et al. 1985).

Respiration. The microbial consumption of oxygen by organisms associated with particles $>2 \mu \mathrm{m}$ in diameter was measured in the dark at in situ temperature with a modified oxygen gradient technique (Kepkay et al. 1986). Samples $(10 \mathrm{ml})$ were pipetted into polycarbonate chambers and filtered through $0.2 \mu \mathrm{m}$ Nuclepore filters. The same volume of filter-sterilized ( $0.2 \mu \mathrm{m}$ filtered) seawater was added to each chamber and oxygen gradients were measured to a distance of 5 $\mathrm{mm}$ above the material collected on the surface of each filter. The gradients allowed calculation of the downward flux of oxygen over a given length of time and, thus, the rate of consumption per $\mathrm{cm}^{2}$ of filter or per $\mathrm{ml}$ of original sample.

\section{RESULTS}

Wind speed decreased from between 12 and $22 \mathrm{~m} \mathrm{~s}^{-1}$ to between 1 and $10 \mathrm{~m} \mathrm{~s}^{-1}$ (Fig. 1) just prior to occupation of the station at $40^{\circ} \mathrm{N}$ for a time series of 5 respira- 

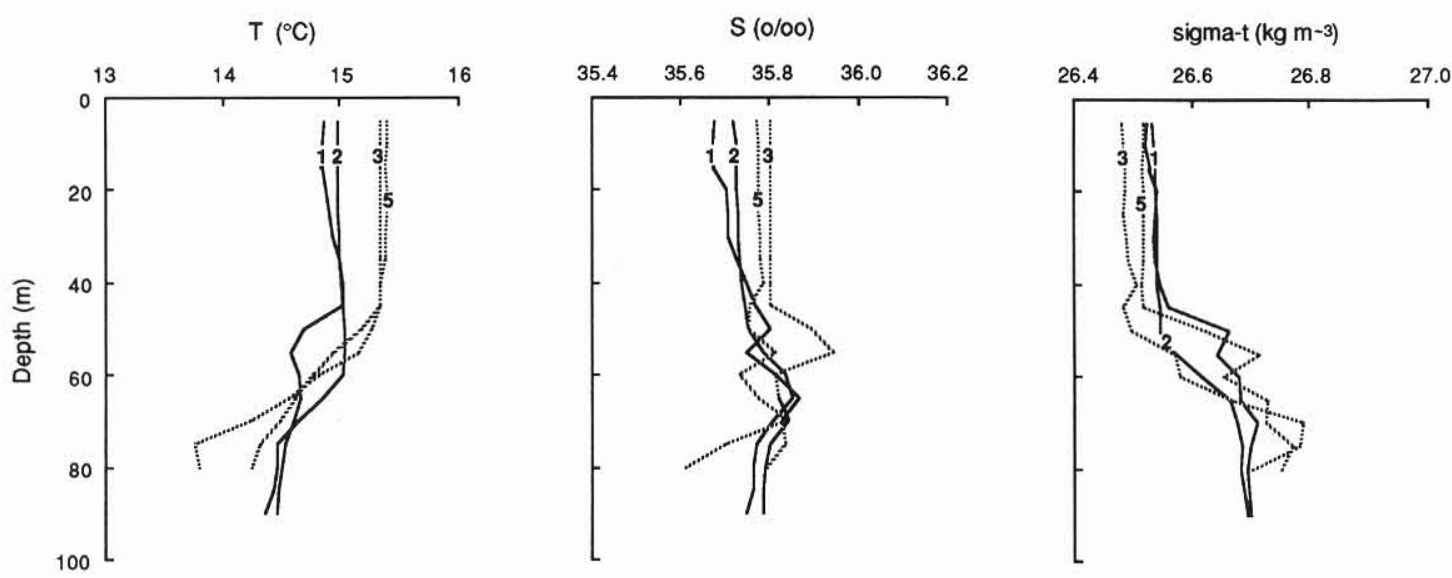

Fig. 2. CTD profiles of temperature, salinity and sigma-t recorded daily during the time series of 5 respiration experiments. Profiles from Day 4 were almost identical to those from Day 5 and have been omitted for clarity to better illustrate the increase of temperature and salinity in the upper 40 to $60 \mathrm{~m}$ of water during the last $3 \mathrm{~d}$ of the time series

tion experiments. Similarly, swell height decreased from between 2.0 and $4.5 \mathrm{~m}$ to between 1 and $2 \mathrm{~m}$. CTD casts (Fig. 2) showed that the mixed layer extended down to between 40 and $60 \mathrm{~m}$ throughout the time series, but there was also a $0.4^{\circ} \mathrm{C}$ increase of temperature and a $0.1 \mathrm{ppt}$ increase of salinity in the upper 40 to $60 \mathrm{~m}$ during Days 3, 4 and 5. Coincident with this increase in temperature and salinity was a decrease in primary production at $10 \mathrm{~m}$ (Table 1). In contrast, chlorophyll concentration at the same depth (Table 1) did not decrease until almost $24 \mathrm{~h}$ later.

During the first $3 \mathrm{~d}$ of the time series, respiration values measured in the bubbled seawaters and unbubbled controls were virtually identical (Fig. 3). These results were in distinct contrast to earlier data from the open ocean (Kepkay \& Johnson 1989, Kepkay et al. 1990a), where short-lived peaks of respiration were observed in bubbled seawaters. However, during Days 4 and 5 (Fig. 3), respiration followed the pattern typical of earlier studies, with strong peaks of oxygen consumption at 2 to $4 \mathrm{~h}$ in bubbled seawaters and far lower, but uniform, oxygen consumption in unbubbled controls. The enhancement of mean respiration over $28 \mathrm{~h}$ by bubbling for $30 \mathrm{~min}$ at time zero (Table 1 ) was almost a mirror image of chlorophyll concentration at $10 \mathrm{~m}$ (Fig. 4), and increased during Days 4 and 5 as chlorophyll decreased.

The time series of bubbling experiments at $44^{\circ} \mathrm{N}$ was carried out at relatively low sea states and with little variation of temperature and salinity in the mixed layer (E. P. Horne unpubl.). In the rebubbling experiment there was a typical peaked response of respiration to the first bubbling of fresh seawater (Fig. 5A). When the bubbled seawater was aged for $24 \mathrm{~h}$ and used in a second experiment, there was no peaked respiratory response and no obvious difference between respiration in the aged, bubbled seawater and the aged, unbubbled control (Fig. 5B).

Table 1. Mean respiration of bubbled and unbubbled seawaters in a $5 \mathrm{~d}$ time series of experiments at $40^{\circ} \mathrm{N}$ in the North Atlantic. Chlorophyll concentration and in situ primary production from a depth of $10 \mathrm{~m}$ are included for comparison to mean respiration

\begin{tabular}{|c|c|c|c|c|c|c|c|c|}
\hline \multirow[t]{2}{*}{$\begin{array}{l}\text { Time } \\
\text { series }\end{array}$} & \multirow{2}{*}{$\begin{array}{l}\text { Time } \\
\text { elapsed } \\
\text { (h) }\end{array}$} & \multicolumn{2}{|c|}{$\begin{array}{l}\text { Respiration (unbubbled SW) } \\
\left(\mu \mathrm{mol} \mathrm{O} \mathrm{I}^{-1} \mathrm{~h}^{-1}\right)\end{array}$} & \multicolumn{2}{|c|}{$\begin{array}{l}\text { Respiration (bubbled SW) } \\
\qquad\left(\mu \mathrm{mol} \mathrm{O} \mathrm{I}^{-1} \mathrm{~h}^{-1}\right)\end{array}$} & \multirow[t]{2}{*}{$\begin{array}{l}\text { Enhancement } \\
\text { factor }^{\mathrm{b}}\end{array}$} & \multirow[t]{2}{*}{$\begin{array}{l}\text { Chlorophyll } \\
\left(\mu \mathrm{g} \mathrm{l}^{-1}\right)^{\mathrm{c}}\end{array}$} & \multirow{2}{*}{$\begin{array}{c}\text { Primary } \\
\text { production } \\
\left(\mu \mathrm{gC} 1^{-1} \mathrm{~h}^{-1}\right)^{\mathrm{d}}\end{array}$} \\
\hline & & Mean $^{a}$ & $\begin{array}{c}\text { Range \& no. of } \\
\text { observations }\end{array}$ & Mean $^{a}$ & $\begin{array}{l}\text { Range \& no. of } \\
\text { observations }\end{array}$ & & & \\
\hline Day 1 & 0 & 0.936 & $0.689-1.844(n=9)$ & 1.000 & $0.689-1.844(\mathrm{n}=9)$ & 1.07 & $2.30 \pm 0.15$ & - \\
\hline Day 2 & 23.6 & 1.191 & $0.748-1.710(n=9)$ & 1.202 & $0.779-1.709(n=9)$ & 1.01 & $2.30 \pm 0.09$ & 2.31 \\
\hline Day 3 & 47.5 & 0.251 & $0.198-0.293(\mathrm{n}=9)$ & 0.257 & $0.197-0.316(n=9)$ & 1.02 & $2.30 \pm 0.31$ & 1.38 \\
\hline Day 4 & 70.9 & 0.497 & $0.092-1.497(n=9)$ & 1.582 & $0.092-8.522(n=9)$ & 3.18 & $1.41 \pm 0.09$ & 1.82 \\
\hline Day 5 & 94.2 & 0.704 & $0.092-4.972(n=9)$ & 2.713 & $0.156-11.77(n=9)$ & 3.85 & $0.98 \pm 0.02$ & - \\
\hline
\end{tabular}




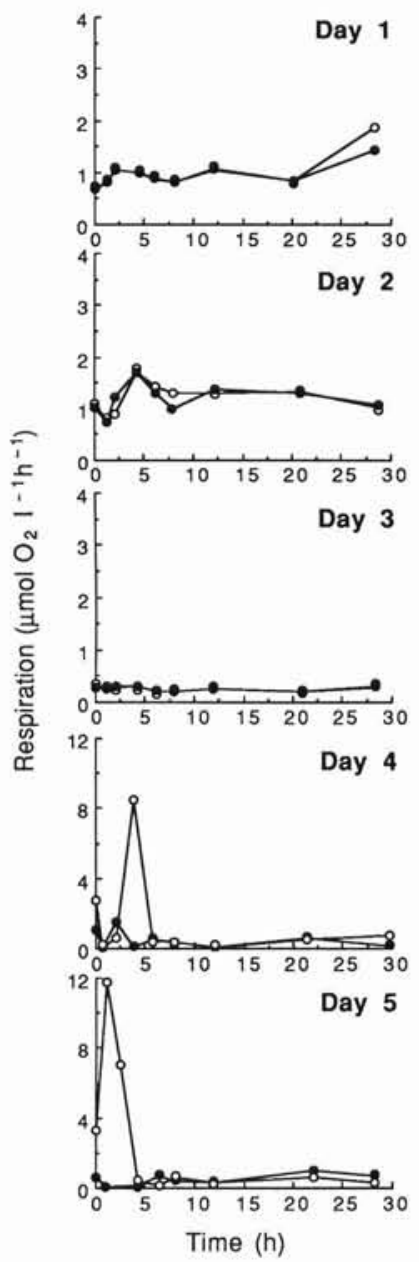

Fig. 3. Results from the time series of 5 respiration experiments. Oxygen consumption rates in seawater from $10 \mathrm{~m}$ are plotted as the results from bubbled samples (0) and unbubbled controls $(\bullet)$. Note the similarity between respiration in the bubbled and unbubbled seawaters during the first $3 \mathrm{~d}$ of the time series and the peaks of respiration measured in bubbled samples during Days 4 and 5

\section{DISCUSSION}

Surface coagulation of DOC in a bubbling column produces a well-defined and rapid respiratory response in water from a wide range of oceanic environments. While the magnitude of this microbial response is variable, a strong peak of oxygen consumption (reaching a maximum within 2 to $4 \mathrm{~h}$ of bubbling) has been repeatedly observed in a wide variety of surface waters (Kepkay \& Johnson 1988, 1989, Kepkay et al. 1990a, b). However, it is important to remember that results from a bubbling column can only be used to estimate the potential for a respiratory response. This potential may or may not be similar in magnitude to the respiration induced by surface coagulation as waves break at the ocean surface. While bubble populations in a glass

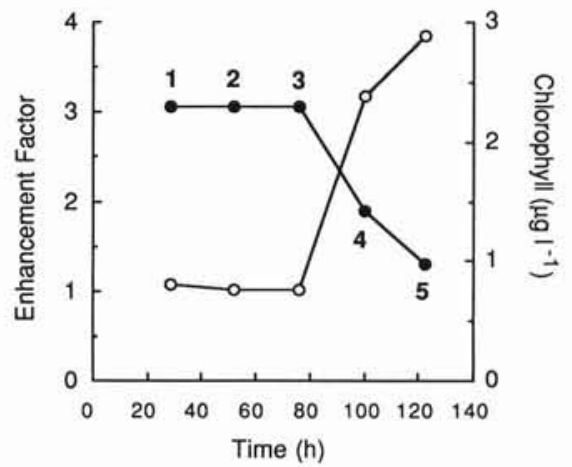

Fig. 4. Enhancement of respiration by bubbling $(0)$ and chlorophyll concentrations $(\bullet)$ for each of the 5 respiration experiments in the time series. The enhancement factor for each experiment is the product of mean respiration (bubbled) over $28 \mathrm{~h}$ divided by mean respiration (unbubbled) over $28 \mathrm{~h}$ (Table 1). Note the increase in enhancement of respiration associated with a decrease in chlorophyll during Days 4 and 5

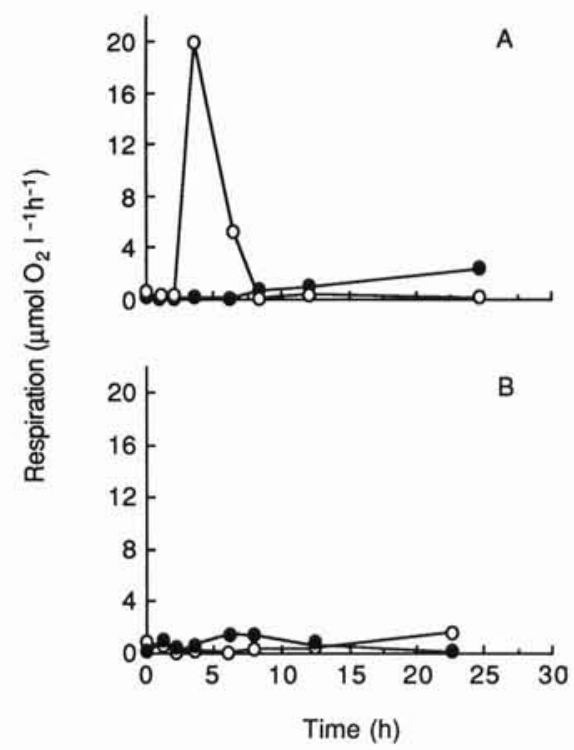

Fig. 5. (A) Respiration in fresh seawater from $10 \mathrm{~m}$ at $44^{\circ} 50^{\prime} \mathrm{N}$, $41^{\circ} 23^{\prime} \mathrm{W}$ in bubbled $(0)$ and unbubbled samples (•). (B) Respiration in bubbled seawater aged for $24 \mathrm{~h}$ is, again, plotted in terms of bubbled $(0)$ and unbubbled samples $(\bullet)$ for comparison

column are not completely representative of those found under a breaking wave, Kepkay \& Johnson (1989) have suggested that data from these columns underestimate, rather than overestimate, the physical and biological effects of surface coagulation.

Given that a bubbling column can provide a reasonably conservative estimate of the potential for a respiratory response to surface coagulation, an additional important factor remains to be discussed. All previous respiration measurements were collected from surface water taken at poorly-defined sea states with swells of $2 \mathrm{~m}$ or less. The measurements reported here (Fig. 3) were collected with due regard to wind speed and swell 
height (Fig. 1). Once higher sea states (2 to $4.5 \mathrm{~m}$ swells associated with wind speeds of 12 to $22 \mathrm{~m} \mathrm{~s}^{-1}$ ) had subsided, the temperature and salinity profiles of the mixed layer at $40^{\circ} \mathrm{N}$ remained uniform during the first $2 \mathrm{~d}$ of the time series of respiration experiments (Fig. 2). During this period, respiration was virtually identical in both the bubbled seawaters and unbubbled controls (Fig. 3), and there was no evidence of a rapid or peaked respiratory response to surface coagulation. The seawater from $10 \mathrm{~m}$ appeared to have already been bubbled at higher sea states, resulting in a limited potential for the induction of respiration in a bubbling column. This conclusion is supported by results from the rebubbling experiment at $44^{\circ} \mathrm{N}$ (Fig. 5). When compared to respiration in bubbled fresh seawater (Fig. 5A), respiration in the aged and rebubbled seawater exhibited no peaked response (Fig. 5B), and was virtually identical to respiration in the same aged seawater that had been maintained as an unbubbled control.

Respiration during the last $2 \mathrm{~d}$ of the time series (Fig. 3 ) was very different from the initial $3 \mathrm{~d}$, and followed a pattern typical of earlier studies (see e.g. Kepkay \& Johnson 1988, 1989). Well-defined peaks of oxygen consumption were observed at 2 to $4 \mathrm{~h}$ after bubbling, which was in distinct contrast to low rates of consumption in unbubbled controls. The onset of this peaked pattern of respiration in Day 4 of the time series (Fig. 3) could not be directly associated with an abrupt increase of mixed-layer temperature and salinity (Fig. 2) and a corresponding decrease in primary production (Table 1) that took place between Days 2 and 3. Instead, this enhancement of respiration was coincident with a decrease in chlorophyll concentration (Fig. 4), and lagged behind primary production by almost $24 \mathrm{~h}$ (Table 1). The reason why chlorophyll lagged almost a full day behind this decrease in productivity is not known. However, it is clear that the changing physical (Fig. 1) and biological (Fig. 4) characteristics of the mixed layer were not associated with a uniform water mass. Instead, these variations were probably related to the local advection of surface water, which interrupted the time series of measurements collected during the first $3 \mathrm{~d}$. This small-scale advection appeared to be associated with flow caused by turbulence along the southern boundary of the Gulf Stream (E. P. Horne unpubl.).

In conclusion, it appears that physical processes operating on a variety of scales should be considered when interpreting the effects of surface coagulation on microbial respiration. At the very least, wind speeds and swell heights must be known to obtain even an approximate idea of the degree to which a parcel of water has already been prebubbled. This will determine the quan-

This article was presented by Dr T. Platt, Dartmouth, N.S., Canada tity of DOC available for surface coagulation in a bubbling column. An idea of the advective movements of a water mass must also be obtained in relation to its basic biological characteristics because, while they cannot be directly related to bubble injection, these characteristics will determine both the quantity and quality of DOC available for surface coagulation and the induction of respiration. This means that results from a bubbling column can only provide an accurate indication of the potential for a respiratory response to surface coagulation when physical and biological parameters defining the recent history of a water mass are known. Better definition of the biological effects of surface coagulation will only be possible through accurate DOC measurements and the determination of bubble spectra and turbulence associated with respiration near the ocean surface.

Acknowledgements. I thank E. P. Horne and W. G. Harrison for the CTD data, and B. Irwin for data on chlorophyll concentration and primary production.

\section{LITERATURE CITED}

Hedges, J. I. (1987). Organic matter in sea water. Nature, Lond. 330: 205-206

Holm-Hansen, O., Korenzen, C. J., Holmes, R. W., Strickland, J. D. H. (1965). Fluorometric determination of chlorophyll. J. Cons. perm. int. Explor. Mer 30: 3-15

Irwin, B., Caverhill, C., Harrison, W. G., Platt, T. (1985). Primary production in the Sargasso Sea northeast of Bermuda in April 1984. Can. Data Rep. Fish. Aquat. Sci. No. 550

Johnson, B. D., Zhou, X. L., Wangersky, P. J. (1986). Surface coagulation in seawater. Neth. J. Sea Res. 20: 201-210

Kepkay, P. E., Harrison, W. G., Irwin, B. (1990a). Surface coagulation, microbial respiration and primary production in the Sargasso Sea. Deep Sea Res. 37: 145-155

Kepkay, P. E., Johnson, B. D. (1988). Microbial response to organic particle generation by surface coagulation in seawater. Mar. Ecol. Prog. Ser. 48: 193-198

Kepkay, P. E., Johnson, B. D. (1989). Coagulation on bubbles allows the microbial respiration of oceanic dissolved organic carbon. Nature, Lond. 385: 63-65

Kepkay, P. E., Muschenheim, D. K., Johnson, B. D. (1990b). Surface coagulation and microbial respiration at a tidal front on Georges Bank. Cont. Shelf Res. 10: 573-588

Kepkay, P. E., Schwinghamer, P., Willar, T., Bowen, A. J. (1986). Metabolism and metal binding by surface-colonizing bacteria: results of microgradient measurements. Appl. environ. Microbiol. 51: 163-170

Sutcliffe, W. H., Baylor, E. R., Menzel, D. W. (1963). Sea surface chemistry and Langmuir circulation. Deep Sea Res. 10: 233-243

Steemann Nielsen, E. (1952). The use of radioactive carbon $\left({ }^{14} \mathrm{C}\right)$ for measuring organic production in the sea. J. Cons. perm. int. Explor. Mer 18: 117-140

Toggweiler, J. R. (1988). Deep-sea carbon, a burning issue. Nature, Lond. 334: 468

Manuscript first received: July 5, 1990

Revised version accepted: September 21, 1990 